\title{
Electrolysed Water in the Food Industry as Supporting of Environmental Sustainability
}

\author{
Maria Antonietta Colangelo, Marisa C. Caruso, Fabio Favati, \\ Teresa Scarpa, Nicola Condelli, and Fernanda Galgano
}

\begin{abstract}
Food safety is a priority for the food industry and to achieve this result a correct plant sanitation programme is of the utmost importance. Among various disinfection techniques, an emerging one is represented by the use of electrolysed water (EW) as the disinfecting agent. The use of EW is compliant with the desire to find alternatives to chlorination and heat treatments, representing a green cleaning alternative to toxic disinfectants. $\mathrm{EW}$ is an activated liquid, obtained by passing a diluted saline solution $\left(\mathrm{NaCl}, \mathrm{KCl}\right.$ or $\left.\mathrm{MgCl}_{2}\right)$ through an electrolytic cell, thus causing the production from the anode side of electrolysed oxidising water, containing high dissolved oxygen, free chlorine and characterised by a low $\mathrm{pH}$ (2.3-2.7) and a high oxidation-reduction potential (ORP $>1,000 \mathrm{mV})$. At the same time from the cathode side electrolysed reduced water is produced, with high $\mathrm{pH}$ (10.0-11.5), high dissolved hydrogen and low ORP ( -800 to $-900 \mathrm{mV})$. Unlike other chemical disinfectants, EW is not harmful for skin and mucous membranes and is quite easy to handle. Furthermore, the use of EW is relatively inexpensive and, above all, is a sustainable technique. Currently used sanitisers (e.g. glutaraldehyde, formaldehyde, etc.) are effective, but their adverse effects on the environment are well known. Differently from these chemicals, the use of EW has a reduced impact on the environment and because of its properties, it may find several applications in the food industry. In this work, the characteristics and some EW applications as sustainable sanitation technique applied in the food industry are reported and discussed.
\end{abstract}

M.A. Colangelo • M.C. Caruso $\bullet$ T. Scarpa $\bullet$ N. Condelli $\bullet$ F. Galgano $(\triangle)$

School of Agricultural, Forestry, Food and Environmental Sciences, University of Basilicata, Potenza, Italy

e-mail: fernanda.galgano@unibas.it

F. Favati

Department of Biotechnology, University of Verona, Verona, Italy

(C) The Author(s) 2015

A. Vastola (ed.), The Sustainability of Agro-Food and Natural Resource Systems in the Mediterranean Basin, DOI 10.1007/978-3-319-16357-4_25 


\section{Introduction}

Chlorine is commonly used as a disinfectant in food processing industries. However, the continuing outbreaks of food infection raise concerns and doubts about food safety. A large part of the food industry uses hypochlorite as disinfectant, but it is not often used under optimum conditions compromising its effectiveness. The excessive use of this disinfectant involves the presence of undesirable by-product residues on food (Gil et al. 2009). In addition, the chlorine-based disinfectants are a risk for human health and the environment (Ölmez and Kretzschmar 2009). In fact, it is known that from the reaction of chlorine with organic matter are generated carcinogenic halogenated by-products (DBP), for example trihalomethanes (THMs) and halogenated acids (HAAs) (Gil et al. 2009; Singer 1994). Moreover, the use of chlorine allows the production of large amounts of wastewater with high levels of biological oxygen demand (BOD). Chlorine dioxide, ozone, organic acids, peroxyacetic acid, hydrogen peroxide and EW are the main alternative sanitising agents that arouse interest (Ölmez and Kretzschmar 2009). In particular, EW represents a good alternative to chlorination and heat treatments, representing a green cleaning alternative to toxic disinfectants. Unlike other chemical disinfectants, EW is not harmful for skin and mucous membranes and is quite easy to handle. Furthermore, the use of EW is relatively inexpensive and, above all, is a sustainable technique. The cost of use is relatively low; the highest cost is the purchase of an electrolytic unit, but, after the initial investment, the costs are very low, requires only water, salt and electricity (Huang et al. 2008). Another important aspect is the low environmental impact which involves the use of EW. When the EW is in contact with the organic matter or is diluted with ordinary tap water by reverse osmosis, water becomes again "normal". As a result, the impact on the environment is much less negative compared to the use of chemical disinfectants, the use of which is also linked to the difficulties of transporting and storing potentially hazardous chemicals (Nakagawara et al. 1998; Tanaka et al. 1999). On the other hand, the main disadvantage is that EW rapidly loses its antimicrobial activity. The solutions REW and OEW maintain for a limited time their properties (12-21 days), if they are stored away from light and heat. Between the two solutions, the OEW loses its effectiveness more quickly, because the chlorine present in gaseous form is dispersed rapidly by volatilisation, so decays the bactericidal power (Kiura et al. 2002). This sustainable technology is already applied in various countries. Since 2002 in Japan EW is enclosed in the list of permitted food additives; moreover, in the USA the EPA (Environmental Protection Agency) has approved the use of electrolysed water in the food industry (Venturini 2013). 


\section{Electrolysed Water}

EW is an activated liquid, obtained by passing a diluted saline solution $(\mathrm{NaCl}, \mathrm{KCl}$ or $\mathrm{MgCl}_{2}$ ) through an electrolytic cell, thus causing the production from the anode side of electrolysed oxidising water (OEW), containing high dissolved oxygen, free chlorine and characterised by a low $\mathrm{pH}(2.3-2.7)$ and a high oxidation-reduction potential (ORP $>1,000 \mathrm{mV})$. At the same time from the cathode side electrolysed reducing water is produced (REW), with high $\mathrm{pH}$ (10.0-11.5), high dissolved hydrogen and low ORP ( -800 to $-900 \mathrm{mV}$ ) (Huang et al. 2008; Venturini 2013; Rui et al. 2011). Of the two solutions, one, the acidic and oxidiser solution, contains hypochlorous acid $(\mathrm{HOCl})$, hydrogen chloride $(\mathrm{HCl})$ and free gas $\left(\mathrm{O}_{2}\right.$ and $\left.\mathrm{Cl}_{2}\right)$; the other, the basic and the reductant solution, contains sodium hydroxide $(\mathrm{NaOH})$, and, from this, $\mathrm{H}_{2}$ gas is liberated. In Fig. 1, the electrolytic cell for the production of electrolysed water is schematically shown. Using a bath electrolysis without separation baffle, a solution with a $\mathrm{pH}$ close to neutral (6.2-6.5), with a low concentration of free chlorine (NEW), is obtained (Venturini 2013).

Due to its properties, and particularly for its bactericidal effect, EW may find several applications in the agriculture and food industry. The disinfectant action is due to several factors that act synergistically: $\mathrm{pH}$; ORP; presence of free chlorine (the disinfecting action is mainly due to the presence of hypochlorous acid) (Venturini 2013). Additionally, the high redox potential induces the modification of the metabolic flows and influences the ATP production, probably due to the variation of the flow of electrons in the cell (McPherson 1993). HOCl, the most

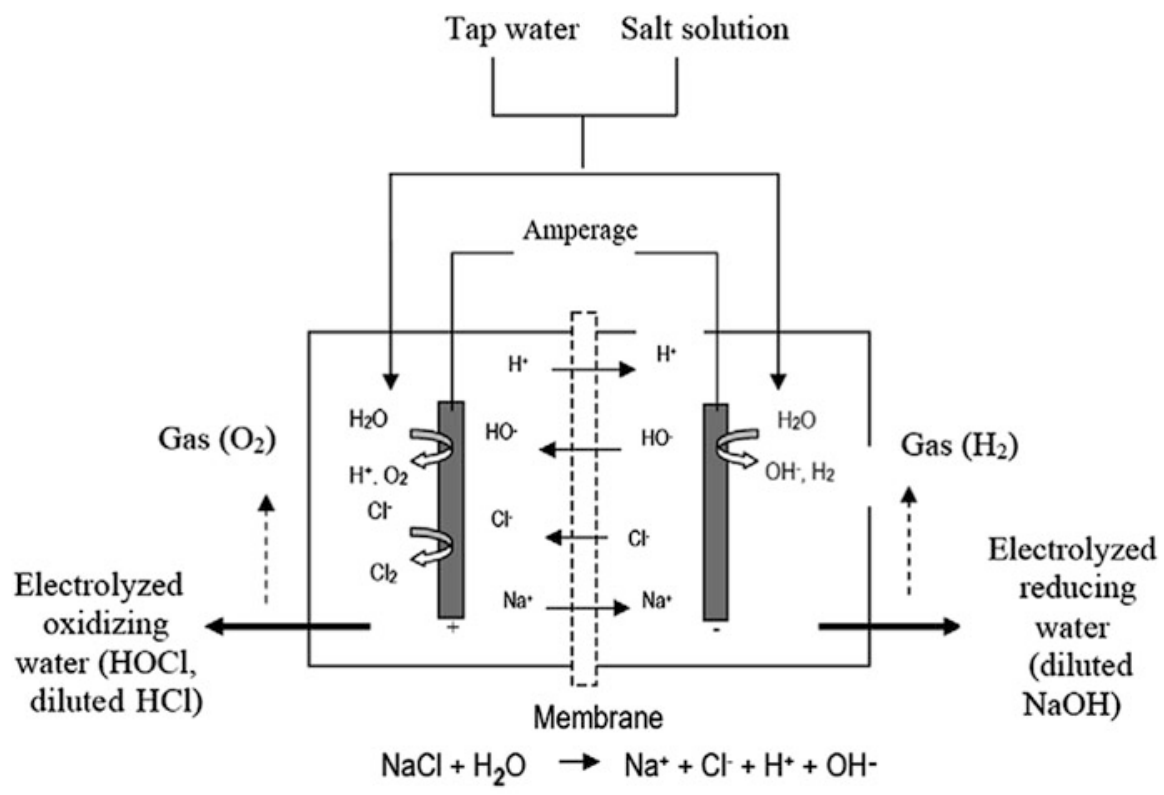

Fig. 1 Scheme of the electrolytic cell for electrolysed water (Venturini 2013) 
active of the compounds of chlorine, seems to be the main responsible for the death of the microbial cell, inhibiting the oxidation of glucose, due to the oxidation of the sulfhydryl groups of enzymes involved in carbohydrate metabolism (Marriott and Gravani 2006).

\section{Application of EW as Surface Disinfectant}

EW has been successfully utilised as surface disinfectant, for example for cutting surfaces made with different materials (glass, steel, glazed ceramic tiles). OEW can be used to reduce bacterial contamination on teflon, stainless steel and ceramic using short treatments (5 min) (Serraino et al. 2010; Park et al. 2002). However, the bactericidal efficacy of EW depends on the amount of organic matter present on the surfaces. In fact, many disinfectants, including hypochlorite, have a reduced effectiveness in presence of a large amount of organic substance (Bach et al. 2006; Liu et al. 2006). This effect can be reduced using the alkaline EW before application of the acidic solution. Alkaline water contains high concentrations of sodium hydroxide, which exerts a detergent action dissolving fats, proteins and polymeric compounds outside the bacterial membranes. In this manner the action of the acid solution will be greater (Ayebah et al. 2005). Møretrø et al. (2012) reported the effectiveness of EW for the disinfection of surfaces contaminated with Salmonella, even in the presence of biofilm. Bartolomé et al. (2011a) used EW for cleaning and disinfecting a circuit milking and cooling tank in a herd of dairy cattle by comparing its effectiveness with traditional cleaning chemicals. In this study, EW has been used as a replacement to a chlorinated alkaline detergent with phosphates and an acid descaling. The obtained results suggested that the EW not only preserves the integrity of the milking systems but also ensures a greater degree of sanitisation, compared to the traditional chemical products, besides being a clean and environmentally friendly system.

\section{EW on Fruits and Vegetables}

The use of EW could be useful also for the treatments of fruits and vegetables, in pre and post-harvest. In fact, in the various studies (Guentzel et al. 2010; Vandekinderen et al. 2009; Tomás-Callejas et al. 2011) is reported that the use of EW, NEW and OEW does not leave significant residues of chlorine and does not affect quality the sensory and nutritional of the fruits and vegetables. In pre-harvest, EW can be used for irrigation inhibiting the microbial growth in water (Phytophthora spp., Fusarium spp., Algae). The OEW can be used to protect products from deterioration post-harvest caused by fungal species, such as Aspergillus, Cladosporium, Penicillium, and from the presence of mycotoxins produced by these fungal species. OEW, diluted with water in a 1:4 ratio, is effective to 
prevent the gray rot of peaches due to the germination of Botrytis cinerea (Venturini 2013). Guentzel et al. (2010) reported about the use of near-neutral EW (pH 6.3-6.5) on surfaces of peaches and grapes to inactivate pure cultures of B. cinerea and Monilinia fructicola responsible of gray mould and brown rot on fruits surfaces. From the study resulted that the dipping and daily spraying treatments prevent the microbial growth better than dipping alone. Moreover, EW is effective for washing and disinfection of fresh-cut fruits and vegetables. The water can represent a vehicle of cross-contamination; for this reason chlorine is usually added to the washing water but EW represents a valid alternative to this practice (Graça et al. 2010; Yudin et al. 2010). Yang et al. (2003) reported that a reduction of Salmonella typhimurium, Escherichia coli O157:H7 and Listeria monocytogenes of $2 \log \mathrm{CFU} / \mathrm{g}$ can be obtained by plunging fresh-cut lettuce in $\mathrm{EW}$ at $\mathrm{pH} 7$, containing $300 \mathrm{mg} / \mathrm{L}$ of free chlorine, for $5 \mathrm{~min}$. Also Abadías et al. (2008) indicated that diluted NEW (50 mg/L free chlorine) has a bactericidal power against E. coli, Salmonella, Listeria innocua and Erwinia carotovara on fresh-cut lettuce, carrot, endive, corn salad and Four season salad. In addition, the result obtained showed that the NEW has an efficacy comparable with $\mathrm{NaClO}(120 \mathrm{mg} / \mathrm{L}$ free chlorine). Tomás-Callejas et al. (2011) used neutral and acidic electrolysed water (AEW) for fresh-cut mizuna baby leaves. The results of the study suggests that EW has a disinfecting power equal to $\mathrm{NaClO}$. Furthermore, NEW has a higher effect against enterobacteria and mesophilic bacteria, while AEW against psychrotrophic and lactic acid bacteria. In another study (Graça et al. 2010) NEW and AEW were used to inactivate food-borne pathogens on the surface of fresh-cut apples, pears and oranges. From this study emerged that both solutions (NEW and AEW) are able to reduce the microbial population, but AEW has a higher efficacy. Deza et al. (2003) reported that the neutral solution had the same or greater efficacy than AEW on the surface of tomatoes. Koide et al. (2009) reported about the use of slightly acidic EW (pH 6, $1.20 \mathrm{mg} / \mathrm{L}$ available chlorine) on fresh cut cabbage. This study showed that slightly acidic EW has a disinfectant efficacy equivalent or higher than $\mathrm{NaClO}$. Gómez-López et al. (2013) investigated about the production of trihalomethanes in baby spinach washed with EW. According to this study, although the EW contains a certain amount of chlorine, it is not involved in the production of dangerous levels of THMs. Even in the washing and cleaning of mushrooms (Pleurotus ostreatus), EW has been useful for the purpose of removing E. coli O157:H7, Listeria, S. typhimurium and Bacillus cereus, which hardly were eliminated with normal washing procedures (Venturini 2013). Ding et al. (2011) also reported about the use of EW with a neutral $\mathrm{pH}(6.2-6.5)$ value and low concentration of free chlorine $(5 \mathrm{mg} / \mathrm{L})$ on oyster mushroom to eliminate foodborne pathogens. The study showed that the EW with neutral $\mathrm{pH}$ and low concentration of free chlorine allows to obtain the same results of using strong acid electrolysed water ( $\mathrm{pH}$ 2.5-2.7, $50 \mathrm{mg} / \mathrm{L}$ available chlorine), with less dangers for human health. Pangloli and Hung (2013) reported that EW with $30 \mathrm{mg} / \mathrm{L}$ of free chlorine can be successfully used to wash blueberries reducing the population of E. coli $\mathrm{O} 157: \mathrm{H} 7$ that may be present. Nimitkeatkai and Kim (2009) observed the effect of EW on washing apples. For the test were used strong acidic EW (pH 2.8) 
and weak acidic EW ( $\mathrm{pH}$ 6.5). The authors assessed the efficacy of the two sanitising solutions, and the better choice is to wash apple with weak acidic EW (either 2 or $5 \mathrm{~min}$ ) or strong acidic $\mathrm{EW}$ for 2 min to preserve sensory quality of apples. Liu et al. (2013) used EW during the production of germinated brown rice (GBR). In fact, although the production of GBR is quite simple, the growth of contaminating microorganisms may constitute a problem. The EW (with different parameters) was used to wash the brown rice. The study showed that the acidic EW promotes the accumulation of gamma-aminobutyric acid (GABA) during the germination of brown rice. The accumulation of GABA is positive because it has many beneficial properties for human health (Liu et al. 2013). Moreover, both strong acidic EW and slightly acidic EW were more effective in inhibiting microbial growth during germination and also promoted the growth of GBR compared with alkaline EW. This aspect has been confirmed in a previous study in which the alkaline EW inhibited the growth of mung bean sprouts; on the contrary, strong acidic EW promoted the growth of mung bean sprouts (Liu et al. 2011). In addition, Rui et al. (2011) studied the application of EW for the washing of mung bean sprouts. The use of EW as washing water, but also of irrigation, was effective for the reduction of populations of Salmonella and E. coli. Issa-Zacharia et al. (2011) used slightly acidic EW (pH 5.6-5.8) on Chinese celery, lettuce and daikon sprouts. The efficacy of the electrolysed solution was compared to sodium hypochlorite solution. It was found that slightly acidic EW is efficacy, as much as the sodium hypochlorite, to reduce the population of indigenous aerobic mesophilic bacteria.

\section{EW on Animal Products}

EW is also effective on animal products against pathogenic microorganisms. For example, the EW can be used to reduce the concentration of E. coli O157:H7, Salmonella spp., L. monocytogenes and Yersinia enterocolitica, conveyed through the faeces, on shell eggs. Normally, prior to incubation, the eggs are subjected to a disinfection treatment that involves the use of formaldehyde, glutaraldehyde or hydrogen peroxide. Although effective, these treatments may have toxic effects, not only on the operator who uses them but also on the chick. The EW achieves the same results in terms of disinfection without toxicity (Favier et al. 2000; Ni et al. 2013; Cao et al. 2009). The washing with EW of chicken carcasses before plucking and evisceration was useful to reduce the risk of cross-contamination and to remove Campylobacter jejuni from the surface of carcasses (Park et al. 2002; Fabrizio and Cutter 2004). Rahman et al. (2012) used both slightly acidic EW (pH 6.2-6.5, $10 \mathrm{mg} / \mathrm{L}$ of available chlorine) and strong acidic EW ( $\mathrm{pH}$ 2.5-2.7, $50 \mathrm{mg} / \mathrm{L}$ of available chlorine) for dipping treatment of fresh chicken breast meat. The results showed that the two solutions have similar antimicrobial activity and not affect negatively the overall sensory quality of meat. On the contrary, EW treatment improved sensory attributes of meat (freshness, texture, odour) and extended the shelf life of the product. Azad et al. (2013) also reported about the 
use of EW, as drinking water, to reduce the oxidative damage to skeletal muscle of broiler chickens exposed to heat stress. The oxidative damage is due to the production of ROS (reactive oxygen species). From the study resulted that the chickens treated with EW water and exposed to a temperature of $34{ }^{\circ} \mathrm{C}$ for 5 days showed higher feed consumption, considerable improved growth performance and lower ROS production compared with the control with normal drinking water. Moreover, Bartolomé et al. (2011b) evaluated the possibility of using EW as drinking water of dairy cattle, and the effects on the quality of milk produced. In milk from cows that had ingested EW, there was a significant reduction in the number of somatic cells and the concentration of coagulase-positive microorganisms. The use of EW for the washing of fresh meat was also investigated. Bosilevac et al. (2005), Fabrizio and Cutter (2004) and Fabrizio et al. (2002) compared the effectiveness of EW with the chlorinated water, ozonated water, acetic acid and trisodium phosphate in reducing the bacterial population on fresh meat. From the studies resulted that the low $\mathrm{pH}$ of acidic $\mathrm{EW}$ allows a greater reduction, compared to the common chlorinated water, of the phenomenon of cross-contamination due to the sequential washes of carcasses. The EW is also effective to inactivate the bacteria present on fish and seafoods. In fact, it is the efficacy to reduce the population of E. coli $\mathrm{O} 157: \mathrm{H7}$ on salmon raw or to prolong the shelf life of yellow fin tuna during chilled and frozen storage (Huang et al. 2006). Phuvasate and $\mathrm{Su}$ (2010) also evaluated the possibility of using EW and EW ice to minimise the growth of histamine-producing bacteria on fish skin and food contact surface. High levels of histamine cause scombroid syndrome, a common illness due to consumption of highly contaminated fish. From this study it resulted that soaking fish skin inoculated with histamine-producing bacteria in EOW (50 ppm) for $120 \mathrm{~min}$ can be obtained a reduction of bacteria slightly higher compared with distilled water treatment, but using EW containing $100 \mathrm{ppm}$ of chlorine resulted in a better reduction of bacteria. The treatment with $\mathrm{EW}$ ice $(100 \mathrm{ppm})$ was very effective to reduce bacteria on fish skin. This result suggested that EW ice treatment, reducing microbial load on fish skin, can reduce the possibility of cross-contamination when fish fillet is prepared. In the same study, EW containing $50 \mathrm{ppm}$ of chlorine resulted in a good sanitiser to eliminate histamine-producing bacteria on food-contact surface. Feliciano et al. (2010) evaluated the efficacy of sanitised ice in reducing bacterial load on fish fillet and in the water collected from the melted ice. The results of this study showed that the sanitised ice allows to reduce the microbial load on raw fish fillet and minimise the microbial growth in water collected from the melted ice. In fact, melting ice may be a reason of cross-contamination if not discarded properly. Furthermore, according to Doi (2002), using a non-diaphragm cell can be produced sterile seawater by filtered seawater and adding $\mathrm{HCl}$ solution. The sterile solution obtained in this manner can be used for the treatment of fish and seafood without affecting taste and smell. In the study of Lin et al. (2014), shrimps were stored under acidic EW ice. From the observations, it appeared that the shrimps in EW ice maintained longer, compared to the sample under traditional ice, their initial characteristics. Particularly, a delay in colour change, a slight variation in the $\mathrm{pH}$, a lower production of volatile basic nitrogen, and no negative 
effect on the texture of the product have been observed. In addition, Wang et al. (2014) reported that using acidic EW ice in dark condition can be obtained a stronger bactericidal effect compared with light condition; in fact, in light condition acidic EW had the highest chlorine loss rate. In this condition, acidic EW ice caused a lower change of $\mathrm{pH}$ compared with the control treated with tap water ice, lower accumulation of alkaline compounds and nitrogenous materials.

\section{Combined Treatments}

In order to increase the efficacy of EW has been proposed its use in combination with other treatments on different foods, without damaging the eco-friendly character of the treatments. Martínez-Hernández et al. (2015) investigated about the use of NEW combined with ultraviolet $\mathrm{C}$ light (UV-C) and with superatmospheric $\mathrm{O}_{2}$ packaging (HO) to reduce Salmonella enteritidis and E. coli on fresh-cut kalianhybrid broccoli. The results showed that NEW + UV-C or NEW $+\mathrm{OH}$ is more effective in reducing pathogens compared with $\mathrm{NaClO}$ or $\mathrm{NEW}$ and $\mathrm{UV}-\mathrm{C}$ alone. On the contrary, the use of triple combination $(\mathrm{NEW}+\mathrm{UV}-\mathrm{C}+\mathrm{OH})$ did not improve the bacteriostatic effect of double combination. Liu et al. (2013) attested that EW in combination with ultrasound has better antimicrobial properties than EW alone. Zhou et al. (2011) used EW in combination with chitosan or carboxymethyl chitosan (CMC) to preserve the characteristics of the puffer fish (Takifugu obscurus) during refrigerated storage. On the product treated with EW + chitosan and EW + CMC was detected a microbial load significantly lower than control (untreated) or than the sample treated with EW alone. However, the combination of EW with chitosan showed better antimicrobial efficacy than the combination of EW with CMC. Rahman et al. (2011) investigated about the combination treatment of alkaline EW and citric acid with mild heat to ensure microbial safety and sensory quality of shredded carrots. The results showed that the dipping in sanitiser solution for $3 \mathrm{~min}$ at $50{ }^{\circ} \mathrm{C}$ is effective to reduce the microbial count but did not influence the tissue, $\mathrm{pH}$ and surface colour of shredded carrots, compared to the untreated control. Similar results were obtained on cabbage, in which the combination of alkaline EW with $1 \%$ of citric acid for 5 min of dipping at $50{ }^{\circ} \mathrm{C}$ has a strong sanitising effect on total count on cabbage (Rahman et al. 2010). Zhou et al. (2012) indicated that the immersion of Nanhui peaches in EW or in EW and 1-methylcyclopropene (MCP) contributes to maintain the colour of peach flesh during storage. In fact, peaches treated with EW or EW-MCP showed lower flesh colour changes, lower production of ethylene, lower changes in polyphenol oxidase and peroxidase activity, compared with untreated fruits. Therefore, was also detected a lower production of malondialdehyde, one of the compounds resulting from oxidation processes. In Table 1 are summarised the main applications of EW on different foods. 
Table 1 Main applications of EW on different foods

\begin{tabular}{|c|c|c|c|}
\hline Food & Results of treatment & Combined treatment & References \\
\hline $\begin{array}{l}\text { Fresh-cut } \\
\text { fruit and } \\
\text { vegetables }\end{array}$ & $\begin{array}{l}\text { EW with different param- } \\
\text { eters was used for wash- } \\
\text { ing or dipping treatment. } \\
\text { It was found that EW is a } \\
\text { good sanitiser and did not } \\
\text { affect the sensory and } \\
\text { nutritional quality of } \\
\text { products. }\end{array}$ & $\begin{array}{l}\text { For fresh cut broccoli was } \\
\text { used EW combined with } \\
\text { UV-C (ultraviolet } \mathrm{C} \text { light) } \\
\text { and } \mathrm{HO} \\
\text { (superatmospheric } \mathrm{O}_{2} \\
\text { packaging). The com- } \\
\text { bined treatment was more } \\
\text { effective in reducing } \\
\text { pathogens compared with } \\
\text { single treatment. }\end{array}$ & $\begin{array}{l}\text { Vandekinderen } \\
\text { et al. (2009), Tomás- } \\
\text { Callejas et al. (2011), } \\
\text { Graça et al. (2010), } \\
\text { Yang et al. (2003), } \\
\text { Abadías et al. (2008), } \\
\text { Deza et al. (2003), } \\
\text { Koide et al. (2009), } \\
\text { Martínez-Hernández } \\
\text { et al. (2015) }\end{array}$ \\
\hline $\begin{array}{l}\text { Germinated } \\
\text { brown rice } \\
\text { (GBR) } \\
\text { Mung bean } \\
\text { sprouts }\end{array}$ & $\begin{array}{l}\text { EW with different param- } \\
\text { eters was used as washing } \\
\text { water but also for irriga- } \\
\text { tion. It resulted that AEW } \\
\text { was more effective in } \\
\text { inhibiting microbial } \\
\text { growth during germina- } \\
\text { tion and promoted the } \\
\text { growth of GBR and mung } \\
\text { bean sprouts. }\end{array}$ & $\begin{array}{l}\text { On GBR EW in combina- } \\
\text { tion with ultrasound had } \\
\text { better antimicrobial prop- } \\
\text { erties than EW alone. }\end{array}$ & $\begin{array}{l}\text { Rui et al. (2011), Liu } \\
\text { et al. }(2011,2013)\end{array}$ \\
\hline $\begin{array}{l}\text { Shredded } \\
\text { carrots and } \\
\text { cabbage }\end{array}$ & & $\begin{array}{l}\text { EW + citric acid is effec- } \\
\text { tive to reduce the micro- } \\
\text { bial count but did not } \\
\text { influence the tissue, pH } \\
\text { and colour, compared to } \\
\text { untreated control. }\end{array}$ & $\begin{array}{l}\text { Rahman et al. (2010, } \\
\text { 2011) }\end{array}$ \\
\hline $\begin{array}{l}\text { Peaches and } \\
\text { grapes blue- } \\
\text { berries } \\
\text { apples }\end{array}$ & $\begin{array}{l}\text { The washing treatment } \\
\text { with EW was effective to } \\
\text { preserve the overall qual- } \\
\text { ity of the products and } \\
\text { reduce the population of } \\
\text { microorganism that cause } \\
\text { loss in quality. }\end{array}$ & $\begin{array}{l}\text { EW + MCP } \\
\text { (1-methylcyclopropene) } \\
\text { was used for washing of } \\
\text { Nanhui peaches. It was } \\
\text { observed lower flesh col- } \\
\text { our changes and lower } \\
\text { production of ethylene } \\
\text { and peroxidase activity, } \\
\text { compared with untreated } \\
\text { fruits. }\end{array}$ & $\begin{array}{l}\text { Guentzel et al. (2010), } \\
\text { Pangloli and Hung } \\
\text { (2013), Nimitkeatkai } \\
\text { and Kim (2009), Issa- } \\
\text { Zacharia et al. (2011), } \\
\text { Zhou et al. (2012) }\end{array}$ \\
\hline $\begin{array}{l}\text { Chinese cel- } \\
\text { ery, lettuce, } \\
\text { daikon } \\
\text { sprouts }\end{array}$ & $\begin{array}{l}\text { The slightly AEW was } \\
\text { effective, as much as the } \\
\text { sodium hypochlorite, to } \\
\text { reduce the population of } \\
\text { indigenous aerobic } \\
\text { mesophilic bacteria. }\end{array}$ & & $\begin{array}{l}\text { Issa-Zacharia } \\
\text { et al. (2011) }\end{array}$ \\
\hline $\begin{array}{l}\text { Baby } \\
\text { spinach }\end{array}$ & $\begin{array}{l}\text { The EW is not involved in } \\
\text { the production of danger- } \\
\text { ous levels of THM. }\end{array}$ & & $\begin{array}{l}\text { Gómez-López } \\
\text { et al. (2013) }\end{array}$ \\
\hline
\end{tabular}


Table 1 (continued)

\begin{tabular}{|c|c|c|c|}
\hline Food & Results of treatment & Combined treatment & References \\
\hline $\begin{array}{l}\text { Oyster } \\
\text { mushroom }\end{array}$ & $\begin{array}{l}\text { EW with a neutral pH } \\
\text { (6.2-6.5) was used to } \\
\text { wash mushroom. The } \\
\text { treatment had the same } \\
\text { disinfectant efficacy of } \\
\text { strong acidic EW. }\end{array}$ & & Graça et al. (2010) \\
\hline Eggs & $\begin{array}{l}\text { The EW gave good results } \\
\text { in terms of disinfection } \\
\text { without toxicity for chick } \\
\text { compared to the treatment } \\
\text { with formaldehyde, glu- } \\
\text { taraldehyde or hydrogen } \\
\text { peroxide. }\end{array}$ & & $\begin{array}{l}\text { Favier et al. (2000), Ni } \\
\text { et al. (2013) }\end{array}$ \\
\hline Meat & $\begin{array}{l}\text { Reduction of microorgan- } \\
\text { isms from the surface of } \\
\text { carcasses. The treatment } \\
\text { did not affect the overall } \\
\text { sensory quality, compared } \\
\text { with the common chlori- } \\
\text { nated water. }\end{array}$ & & $\begin{array}{l}\text { Fabrizio and Cutter } \\
\text { (2004), Rahman } \\
\text { et al. (2012), } \\
\text { Bosilevac } \\
\text { et al. (2005), Fabrizio } \\
\text { et al. (2002) }\end{array}$ \\
\hline $\begin{array}{l}\text { Milk and } \\
\text { poultry }\end{array}$ & $\begin{array}{l}\text { EW was used as drinking } \\
\text { water for cows and broiler } \\
\text { chickens. The treatment } \\
\text { positively affected the } \\
\text { quality of milk from cows } \\
\text { that had ingested EW and } \\
\text { the growth of chickens. }\end{array}$ & & $\begin{array}{l}\text { Azad et al. (2013), } \\
\text { Bartolomé } \\
\text { et al. (2011b) }\end{array}$ \\
\hline $\begin{array}{l}\text { Fish and } \\
\text { seafoods }\end{array}$ & $\begin{array}{l}\text { The EW ice was effective } \\
\text { to reduce the histamine- } \\
\text { producing bacteria on fish } \\
\text { skin and to preserve the } \\
\text { quality of seafood flesh. }\end{array}$ & $\begin{array}{l}\text { The combined treatment } \\
\text { of EW + Chitosan was } \\
\text { better than EW + CMC } \\
\text { (carboxymethyl chitosan) } \\
\text { for reducing microbial } \\
\text { load and improving the } \\
\text { overall quality of } \\
\text { puffer fish. }\end{array}$ & $\begin{array}{l}\text { Huang et al. (2006), } \\
\text { Phuvasate and Su } \\
\text { (2010), Feliciano } \\
\text { et al. (2010), Lin } \\
\text { et al. (2014), Wang } \\
\text { et al. (2014), Zhou } \\
\text { et al. (2011) }\end{array}$ \\
\hline
\end{tabular}

\section{Conclusions}

From the reported studies, it is evident that the EW represents a sanitising technique as supporting of environmental sustainability. It can be used as disinfectant surface but also for the treatment of food products. In particular, from the cited studies, it resulted that AEW has a better antimicrobial activity compared with NEW. However, in order to preserve the sensory and nutritional quality of food, it is advantageous to use the NEW or slightly AEW. In any case, the effects of EW used in different conditions have to be further investigated depending on the type of food. 
Open Access This chapter is distributed under the terms of the Creative Commons Attribution Noncommercial License, which permits any noncommercial use, distribution, and reproduction in any medium, provided the original author(s) and source are credited.

\section{References}

Abadías M, Usall J, Oliveira M et al (2008) Efficacy of neutral electrolyzed water (NEW) for reducing microbial contamination on minimally-processed vegetables. Int $\mathrm{J}$ Food Microbiol 123(1-2):151-158

Ayebah B, Frank JF, Hung YC (2005) Enhancing the bactericidal effect of oxidizing water on Listeria monocytogenes biofilms formed on stainless steel. J Food Prot 68(7):1375-1380

Azad MAK, Kikusato M, Zulkifli I et al (2013) Electrolysed reduced water decreases reactive oxygen species-induced oxidative damage to skeletal muscle and improves performance in broiler chickens exposed to medium-term chronic heat stress. Br Poult Sci 54(4):503-509

Bach SJ, Jones S, Stanford K et al (2006) Electrolyzed oxidizing anode water as a sanitizer for use in abattoirs. J Food Prot 69(7):1616-1622

Bartolomé D, Posado R, Rodríguez L et al (2011a) Valutazione dell'efficacia dell'acqua elettrolizzata nei circuiti lattieri di aziende di bovini da latte AIDA. XIV Jornadas Sobre Producción Animal 1:13-15

Bartolomé D, Posado R, Rodríguez L et al (2011b) Effetto igienizzante dell'acqua elettrolizzata sull'acqua da bere e sulla qualità igienico-sanitaria del latte AIDA. XIV Jornadas Sobre Producción Animal 1:16-18

Bosilevac JM, Shackelford SD, Brichta DM et al (2005) Efficacy of ozonated and electrolyzed oxidative waters to decontaminate hides of cattle before slaughter. J Food Prot 68 (7):1393-1398

Cao W, Zhu ZW, Shi ZX et al (2009) Efficiency of slightly acidic electrolyzed water for inactivation of Salmonella enteritidis and its contaminated shell eggs. Int J Food Microbiol 130(2):88-93

Deza MA, Araujo M, Garriso MJ (2003) Inactivation of Escherichia coli O157:H7 Salmonella enteriditis and Listeria monocytogenes on the surface of tomatoes by neutral electrolyzed water. Lett Appl Microbiol 37(6):482-487

Ding T, Rahman SME, Oh D (2011) Inhibitory effects of low concentration electrolyzed water and other sanitizers against foodborne pathogens on oyster mushroom. Food Contr 22(2):318-322

Doi T (2002) Characteristics and utilization of slightly acidic electrolyzed water. Food Ind 45 (10):40-46

Fabrizio KA, Cutter CN (2004) Comparison of electrolyzed oxidizing water with other antimicrobial interventions to reduce pathogens on fresh pork. Meat Sci 68(3):463-468

Fabrizio KA, Sharma RR, Demirci A et al (2002) Comparison of electrolyzed oxidizing water with various antimicrobial interventions to reduce Salmonella species on poultry. Poult Sci 81 (10):1598-1605

Favier GI, Escudero ME, Velázquez L et al (2000) Reduction of Yersinia enterocolitica and mesophilic aerobic bacteria in egg-shell by washing with surfactants and their effect on the shell microstructure. Food Microbiol 17(1):73-81

Feliciano L, Lee J, Lopers JA et al (2010) Efficacy of sanitized ice in reducing bacterial load on fish fillet and in the water collected from the melted ice. J Food Sci 75(4):231-238

Gil MI, Selma MV, López-Gálvez F et al (2009) Fresh-cut product sanitation and wash water disinfection: problems and solutions. Int J Food Microbiol 134(1-2):37-45

Gómez-López VM, Marín A, Medina-Martínez MS et al (2013) Generation of trihalomethanes with chlorine-based sanitizers and impact on microbial, nutritional and sensory quality of baby spinach. Postharvest Biol Technol 85:210-217 
Graça A, Nunes C, Salazar M (2010) Efficacy of neutral and acid electrolyzed water for reducing microbial contamination on fresh-cut fruits. Acta Hortic 877:649-656

Guentzel JL, Lam KL, Callan MA et al (2010) Postharvest management of gray mold and brown rot on surfaces of peaches and grapes using electrolyzed oxidizing water. Int J Food Microbiol 143(1-2):54-60

Huang YR, Hsieh HS, Lin SY et al (2006) Application of electrolyzed oxidizing water on the reduction of bacterial contamination for seafood. Food Contr 17(12):987-993

Huang YR, Hung YC, Hsu SY et al (2008) Application of electrolyzed water in the food industry. Food Contr 19(4):329-345

Issa-Zacharia A, Kamitani Y, Miwa N et al (2011) Application of slightly acidic electrolyzed water as a potential no-thermal food sanitizer for decontamination of fresh ready-to-eat vegetables and sprouts. Food Contr 22(3-4):601-607

Kiura H, Sano K, Morimatsu S et al (2002) Bactericidal activity of electrolyzed acid water from solution containing sodium chloride at low concentration, in comparison with that at high concentration. Int J Microbiol Methods 49(3):285-293

Koide S, Takeda J, Shi J et al (2009) Disinfection efficacy of slightly acidic electrolyzed water on fresh cut cabbage. Food Contr 20(3):294-297

Lin T, Wang JJ, Li JB et al (2014) Use of acidic electrolyzed water ice for preserving the quality of shrimp. J Agric Food Chem 61(36):8695-8702

Liu C, Chen WM, Xiao XM (2006) Effect of electrolyzed oxidizing water on reducing Listeria monocytogenes contamination on seafood processing surfaces. Int J Food Microbiol 72 (3):77-83

Liu R, Hao JX, Liu HJ et al (2011) Application of electrolyzed functional water on producing mung bean sprouts. Food Contr 22(8):1311-1315

Liu R, He X, Shi J et al (2013) The effect of electrolyzed water on decontamination, germination and $\gamma$-aminobutyric acid accumulation of brown rice. Food Contr 33(1):1-5

Marriott NG, Gravani RB (2006) Principles of food sanitation, 5th edn. Springer, New York, pp 25-30

Martínez-Hernández GB, Navarro-Rico J, Gómez PA et al (2015) Combined sustainable sanitizing treatments to reduce Escherichia coli and Salmonella enteritidis growth on fresh-cut kalianhybrid broccoli. Food Contr 47:312-317

McPherson LL (1993) Understanding ORP's role in the disinfection process. Water Eng Manag 140(8):29-31

Møretrø T, Heir E, Nesse LL et al (2012) Control of Salmonella in food related environments by chemical disinfection. Food Res Int 45(2):532-544

Nakagawara S, Goto T, Nara M (1998) Spectroscopic characterization and the pH dependence of bactericidal activity of the aqueous chlorine solution. Analyt Sci 14(4):691-698

Ni L, Li BM, Cao W, et al (2013) Spraying efficiency of slightly acidic electrolyzed water for reduction foodborne pathogens and natural microflora on shell eggs. American Society of Agricultural and Biological Engineers Annual International Meeting, 4:2687-2693

Nimitkeatkai H, Kim JG (2009) Washing efficiency of acidic electrolyzed water on microbial reduction and quality of Fuji Apples Korean. J Hortic Sci Technol 27(2):250-255

Ölmez H, Kretzschmar U (2009) Potential alternative disinfection methods for organic fresh-cut industry for minimizing water consumption and environmental impact. LWT-Food Sci Technol 42(3):686-693

Pangloli P, Hung Y (2013) Reducing microbiological safety risk on blueberries through innovative washing technologies. Food Contr 32(2):21-625

Park H, Hung YC, Kim C (2002) Effectiveness of electrolyzed water as a sanitizer for treating different surfaces. J Food Prot 65(8):1276-1280

Phuvasate S, Su Y (2010) Effects of electrolysed oxidizing water and ice treatments on reducing histamine-producing bacteria on fish skin and food contact surface. Food Contr 21(3):286-291

Rahman SME, Jin Y, Oh D (2010) Combined effects of alkaline electrolyzed water and citric acid with mild heat to control microorganisms on cabbage. Food Microbiol Saf 75(2):111-115 
Rahman SME, Jin Y, Oh D (2011) Combination treatment of alkaline electrolyzed water and citric acid with mild heat to ensure microbial safety, shelf-life and sensory quality of shredded carrots. Food Microbiol 28(3):484-491

Rahman SME, Park J, Song KB et al (2012) Effect of slightly acidic low concentration electrolyzed water on microbiological, physicochemical, and sensory quality of fresh chicken breast meat. J Food Sci 71(1):35-41

Rui L, Jianxiong H, Haijie L et al (2011) Application of electrolyzed functional water on producing mung bean sprouts. Food Contr 22(8):1311-1315

Serraino A, Veronese G, Alonso S et al (2010) Bactericidal activity of electrolyzed oxidizing water on food processing surfaces. Int J Food Sci 22(2):221-228

Singer PC (1994) Control of disinfection by-products in drinking water. J Environ Eng-ASCE 120 (4):727-744

Tanaka N, Fujisawa T, Daimon T et al (1999) The effect of electrolyzed strong acid aqueous solution on hemodialysis equipment. Artif Organs 23(12):1055-1062

Tomás-Callejas A, Martínez-Hernández GB, Artés F et al (2011) Neutral and acidic electrolyzed water as emergent sanitizers for fresh-cut mizuna baby leaves. Postharvest Biol Technol 59 (3):298-306

Vandekinderen I, Van Camp J, De Meulenaer B et al (2009) Moderate and high doses of sodium hypochlorite, neutral electrolyzed oxidizing water, peroxyacetic acid, and gaseous chlorine dioxide did not affect the nutritional and sensory qualities of fresh-cut iceberg lettuce (Lactuca sativa Var. capitata L.) after washing. J Agric Food Chem 57(10):4195-4203

Venturini MC (2013) Acqua elettrolizzata: tecnologia emergente del settore ortofrutticolo. Alim Bev 4:50-55

Wang JJ, Lin T, Li JB et al (2014) Effect of acidic electrolyzed water ice on quality of shrimp in dark condition. Food Contr 35(1):207-212

Yang H, Swem BL, Li Y (2003) The effect of pH on inactivation of pathogenic bacteria on freshcut lettuce by dipping treatment with electrolyzed water. Food Microbiol Saf 68(3):1013-1017

Yudin R, Zuñiga M, Vergara J (2010) Revisiting the use of electrolyzed water as a fresh produce sanitizer. Acta Hortic 906:225-234

Zhou R, Liu Y, Xie J, Wang X (2011) Effects of combined treatment of electrolized water and chitosan on the quality attributes on myofibril degradation in farmed obscure puffer fish (Takifugu obscurus) during refrigerated storage. Food Chem 129(4):1660-1666

Zhou R, Zhang G, Hu Y et al (2012) Reductions in flesh discolouration and internal morphology changes in Nanhui peaches (Prunus persica (L.) Batsch, cv. Nanhui) by electrolyzed water and 1-methylcyclopropene treatment during refrigerated storage. Food Chem 135(3):985-992 